日平滑筋誌 (Jap. J. Smooth Muscle Res.) 3, 45-53, 1967.

\title{
植込夕電極法食道筋電図
}

\author{
千葉大学医学部 佐藤外科教室 \\ 佐藤 博, 平島 毅, 西村 明, 塩田彰郎, 田 紀克 \\ 佐々木守, 原 輝彦, 大山修身, 三好弘文

\section{AN ELECTROMYOGRAPHICAL STUDY OF THE ESOPHAGUS WITH CHRONICALLY IMPLANTED ELECTRODES}

\author{
Hiroshi Sato, Tsuyoshi Hirashima, Akira Nishimura, Akio Shiota, Norikatsu Den, \\ Mamoru Sasaki, Teruhiko Hara, Osami Oyama, Hirofumi Mryoshi
}

The Second Surgical Department, Chiba University, Chiba.

The electromyogram of the esophagus has been studied by means of intramuscularly implanted electrodes to investigate pathophysiological changes seen in experimentally produced achalasia-like condition in dogs. These studies have been attempted to elucidate the functional mechanism of the esophagogastric junction.

Electrodes are implanted into the esophageal muscle at 4 different points; the upper, middle, lower parts of the esophagus and the esophagogastric junction respectively and the electrodes have been kept chronically. In dogs, the electromyogram is taken during spontaneous swallowing without anesthesia or restraint while the studies are done.

After the electrodes have been connected with the multi-channel amplifier, the electromyogram can be easily recorded until 3 weeks postoperatively.

One day after the operation, dogs can eat and the electromyographical bursts move down to the lower part of the esophagus, judging from the electromyographical patterns at the 4 different points. The bursts are high in the maximum amplitude and long in the duration at the lower part of the esophagus as compared with the one from the upper part. Changes are slight in amplitude at the esophagogastric junction.

緒

特発性食道拡張症は 1672 年 Willis ${ }^{1)}$ により始めて報 告されて以来, 幾多の研究があるにも拘らず, その病因 病態は, 今日なお十分には解明されていない. 本症の病 因・病態究明のため, 教室では, 臨床検査, または, 動 物実験, あるいは特発性食道拡張症様動物作成, または 食道運動の記録，及び組織の変化など，多面にわたり， その研究を進めている. 食道運動の検索にあたっては, 食道鏡による観察, レ線透視撮影, 電気圧力計を用いて の open-tip 法による内圧測定，及び，平滑筋筋電図記 録を行なっているが，われわれは筋電図を用いて食道運 動を研究した。

平滑筋筋電図については，Alvarez2)(1914)及び，Bozler3,4) (1938) 以来, 洺くの業績があるが，食道筋電困 に関する発表は数える程しかない.すなわち, Brücke- 井 上5) (1912), Brücke-佐武6) (1913), 横沢7) (1955), 甲

\section{言}

田8) (1955), 谷原 ${ }^{9)}(1958)$, 多田10) (1959), 及び, 水 野11) (1964) などの発表である.しかし，てれらはいづ れも, 摘出超生実験, または, 無麻酔拘束下, または, 麻酔下のものであり, 生理的な状態とはや〉離れた感が ある.そこで, われわれは, 新たに, 慢性植込み電極法 を食道に応用し，食道の筋電図を記録した。乙の方法の 特徵は, 無麻酔無拘束であるので, 自発的な㫶下による 最も生理的な食道運動が記録でき，さらに同一部位か ら, 同一条件で長期にわたり経時的に食道筋電図が記録 できるので, 薬剤, または, 迷走神経切除の影響の検索 に好適であることである.

との植込み電極法食道筋電困において, 可成り明確な burst を記録し得たので，今回はその生理的な成績を中 心にして報告する. 
実 験 方 法

8〜 $15 \mathrm{~kg}$ の成犬 12 頭の食道に植込み電極法を施行し た. Nembutal $25 \mathrm{mg} / \mathrm{kg}$ 静注で麻酔した後, 気管内挿管 し，補助呼吸ができるようにしておき，右第 5 肋間で開 胸し, 肺を圧排して食道に達した。

電極は鈎状双極針電極 ${ }^{122}$ で，材質は鉄であり，極間 抵抗は $12 \mathrm{k} \Omega$ である. 電極の太さは $300 \mu$, 極間距離は $1 \mathrm{~mm}$, 長さは $3.5 \mathrm{~mm}$ で, 先端 $1 \mathrm{~mm}$ を残してカシュ 一で絶縁してある (第 1 図, 左)。電極のリード線は 20 $\mathrm{cm}$ であり, その先端はソケットになっており, 記録器 と容易に接合できるようになっている.

ての電極を食道に管外性に刺入するのだが，その部位 は，胸部食道の奇静脈交叉部より $1 \mathrm{~cm}$ 上方，奇静脈弓 と模隔膜との間を 2 分してそれぞれの中点，および食道
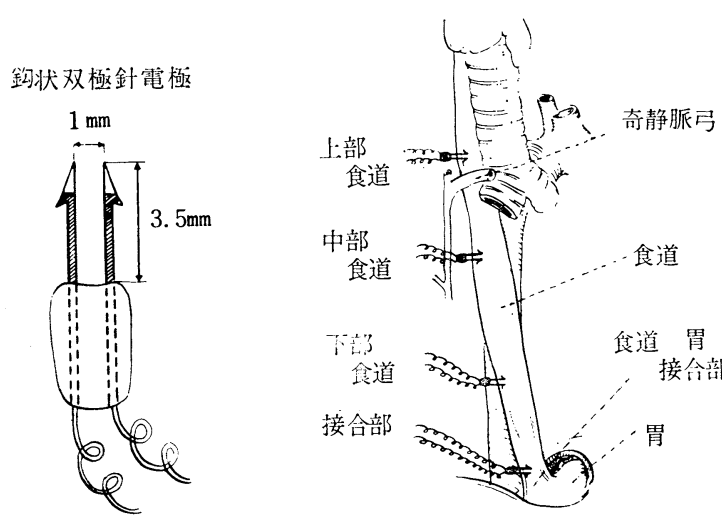

図 1. 食道筋電圀誘導電極及び誘導部位

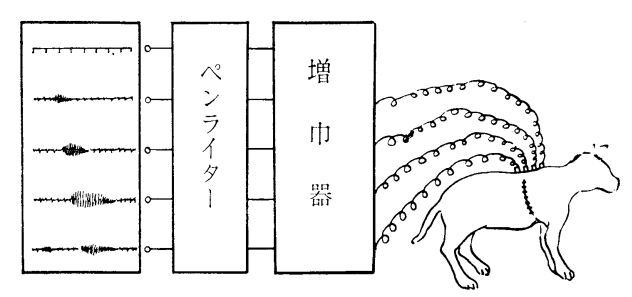

図 2. 食道筋電図記録法（植込み電極法）

胃接合輪より $1 \mathrm{~cm}$ 上方の 4 点であり，それぞれ，上部 食道，中部食道，下部食道，および，接合部と規定した (図 1, 右).乙の際, 電極は采にて食道壁に結絷され， 更には器質化され，確実に食道筋層に固定された。

この電極のリード線は, 胸腔内背側に 沿い肺を迂回 し, 開胸創背側端より胸腔を出, 皮下を通して, 背部正 中線の上方より体外に出して, ソヶットの部で皮膚に固 定された。乙れは四肢, および，口の死角になると思わ れる部位である.

食道筋電図記録時には，てのソケットを筋電図誘導用 入力箱に接続し, てれより増巾器を経て, 4 素子インク 書きオッシログラフ (日本光電製多記録装置, RM 150) 亿連結した（図 2 ).なお，時定数は 0.01 秒，記録速度 は $1 \mathrm{~cm} / \mathrm{sec}$ とし。

以上の如く装置し，イヌに水，または，菓子を䵐下さ せると，食道筋電図では burst を生ずるが，その burst をその持続時間, および，最大振巾の面から検討した。

\section{実 験 成 䋶}

電極植込み後の一般状態

イヌは電極植込み後 1 日で麻酔は完全に醒め, 歩行可
能であり, 食餌を自ら喰べ, その䜩下により, 筋電図で は burst を生ずる。

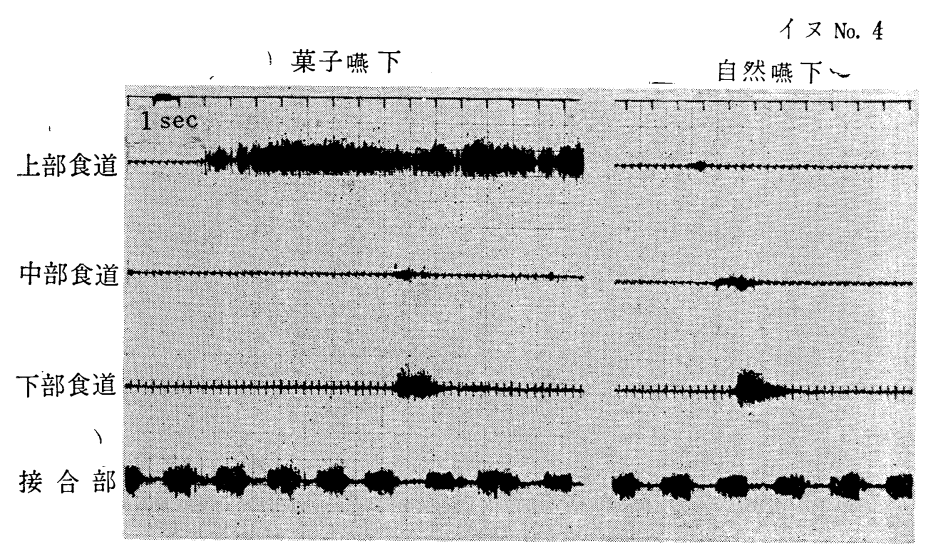

図 3．曣下時食道筋電図（植込み電極法） 
術後 3 日目の出血死 1 例, 1 週間前後にて膿胸による死 亡が 3 例ある他は, 約 3 週間は食道筋電図記録可能であ った。それは，初期の数例は動物の肢，または口によ り，その他のものは犬小屋との強度の接触によりソケッ トがちぎれる事があるからである。

\section{噮下物の差による burst}

固形物鯀下と流動物嚥下との間に，その burst に関し て著明な差は見られなかった。

固形物にしろ，流動物にしろ食慨を持続的に摂取する 時には, 上部食道の筋電困は咬筋または, 首の運動に影 響され持続的な spike を示し，典型的な burst は見ら れなかった（図 3 左).一方，自然燕下 (dry swallowing) の際は, 食道上方より下方へ典型的な型の burst が次に 移行する (図 3 右). てれと同じ型の burst は, 少量の 水を飲ませ，一口嚥下させるととにより誘発されたの で, 以後 burst の検討は水一口嬩下によるものについて 行なった.

\section{食道筋電図の一般的性翼}

安静時食道筋電困には, 上部食道, 中部食道, 下部食 道，接合部にわたり心電困が見られ，接合部には模隔膜 の呼吸運動に一致する振巾の小さい規則的な burst が見 られる他はなんら電気的変化はない.

水一口嚥下による食道筋電図で, burst は先ず, 上部 食道に発生するが，一定の潜時をおいて，中部食道，下 部食道，接合部の順に生ずる（図 4, 図 5). burst は紡 鏵型に近い型をしており，その持続時間，および最大振 巾を計測したが，睘下運動により基線が動摇する時は，

一時点の振巾の最大のものを最大振巾とした。

\section{経時的 burst}

篧下時食道筋電図は電極植込み後 1 日目から採取可能 であり，2-3 週間にわたり記録した。図 4, 図5 はその 1 例である. 電極植込み後 1 日目の burst の最大振巾, および持続時間はやや大であるが，その後の burstはは ぼ同じ大きさである。

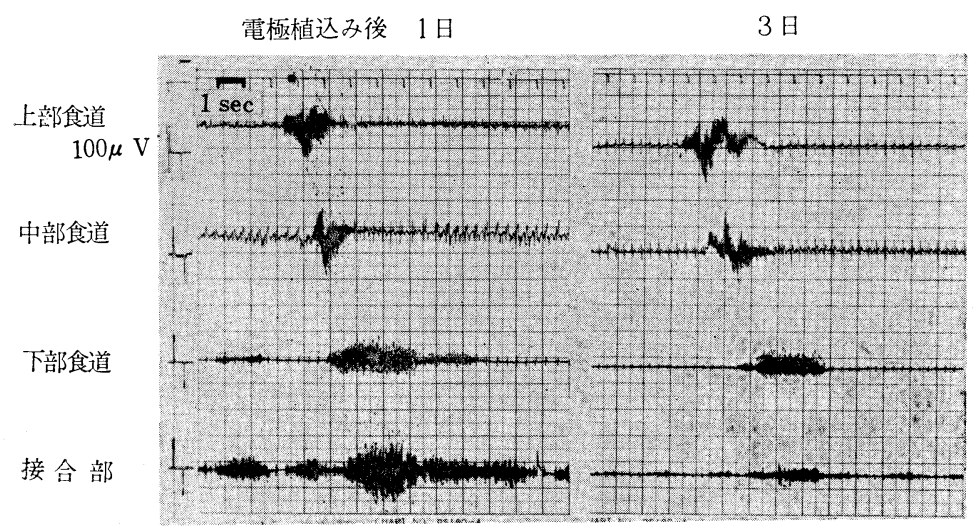

図 4. 藻下诗食道筋電図 (植込み電極法)

イヌ No 7

電婳植込み後 7 日

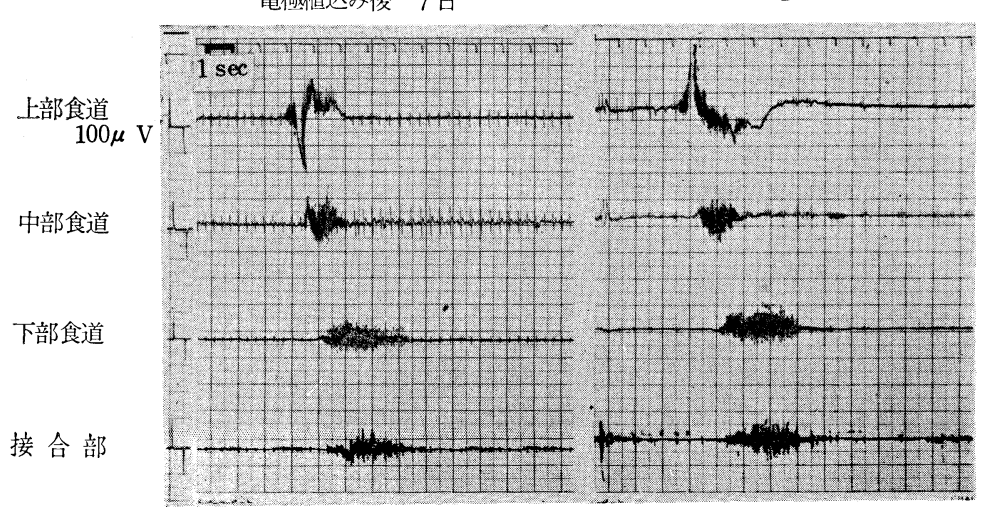

図 5. 喼下時食道筋電図（植込み電極法） 
最大振门平均值

イヌ No. 4
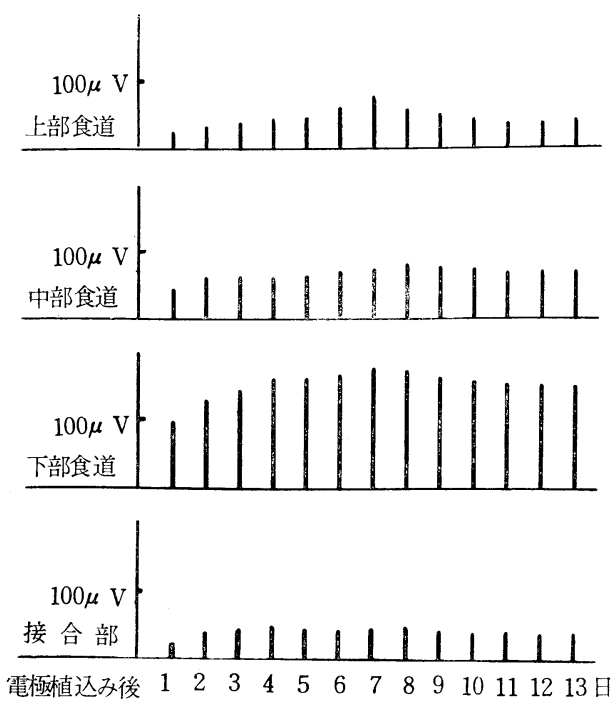

図 6. 燕下時食道筋電図の経時的変化

他の 1 例について, 電極植込み後各日の嚥下による burst の最大振巾の平均值を誘導部位別に見たものが図 6 である. 電極植込み後 4 日目以後はほぼ一定の值をと り，2，3 日目の值もこれに近い.

全例について, burst の最大振巾，および持続時閒を 見ると，電極植込み後 1 日目には大なるととも，小なる こともあるが，2 日目以後は殆んど正常に近づき, 全経 過を通して，ほぼ一定していた。そてで，各誘導部位別 の burst の性質を検索するにあたっては，電極植込み 2 日目以後のものを対象とした.

\section{誘導部位別 burst}

水一口嚥下による 282 ケの burst の最大振巾，およ び，持続時間について，誘導部位別に比較検討した。
最大振巾は上部食道で $15 \sim 160 \mu \mathrm{V}$ の間に分布し平均 值 $83 \mu \mathrm{V}$ であり, 中部食道で $40 \sim 200 \mu \mathrm{V}$ の間に分布し 平均值 $135 \mu \mathrm{V}$ であり，下部食道で $100 \sim 200 \mu \mathrm{V}$ の間 に分布し平均值 $149 \mu \mathrm{V}$ であり, 食道胃接合部で 15 $130 \mu \mathrm{V}$ の間に分布し平均值 $83 \mu \mathrm{V}$ である.

持続時間は上部食道で $0.35 \sim 2.8$ 秒の間に分布し平均 值 1.58 秒であり，中部食道で $0.9 \sim 4.0$ 秒の間に分布 し平均值 2.78 秒であり，下部食道で $1.2 \sim 5.5$ 秒の間 に分布し平均值 2.86 秒であり，食道胃接合部で 1.3 4.5 秒の間に分布し平均值 2.78 秒である. てれらの值 の分布する範囲を破線で，平均值を実線で示したものが
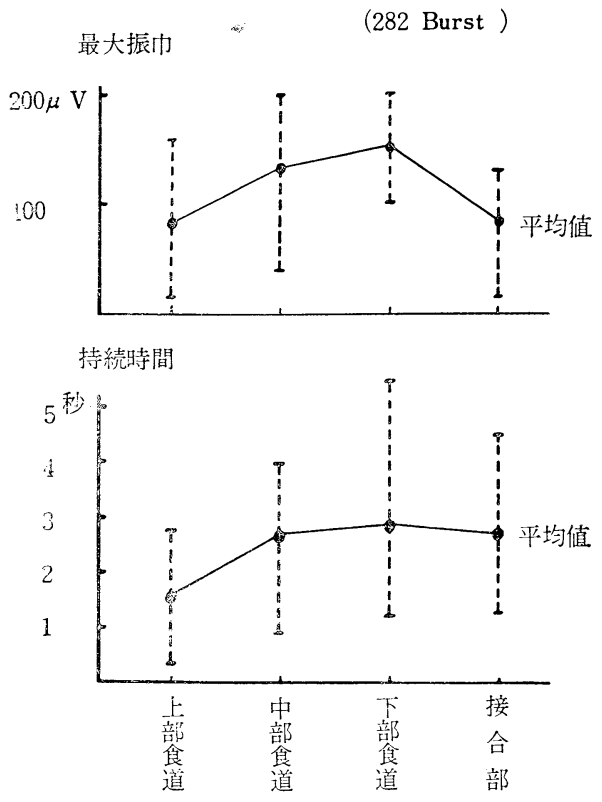

図 7. 最大振巾及び持続特間の平均値

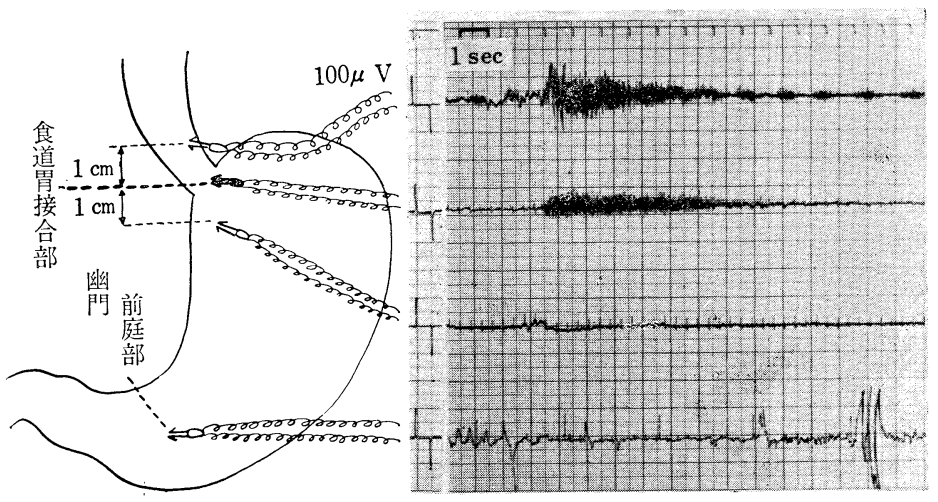

図 8. 蟮下時食道・胃接合部及び胃筋電図（植込み電極法） 
図 7 である.最大振巾，および，持続時間の平均值は， 食道上部より下方に行くにつれ 次第に大きくなってい る.しかし，食道胃接合部では最大振巾は減少してお り，乙の部の特異性がうかがわれる.

\section{食道胃接合部の burst}

食道胃接合部に図 8 の如く電極を刺入し, 笳電図を記 録した，食道胃接合輪より $1 \mathrm{~cm}$ 上は食道胃接合部とし ていた部位で，呼吸運動による小さな burst があり，乙 ১に㖟下による著明な burstが重なる.てれより下の接 合輪の burst の振巾は更に小さくなり, burst はこの部
で終り，接合輪より $1 \mathrm{~cm}$ 下では現われない。なお，胃 に於ては，喛下による burst とは無関係に，自発的な burst が周期的に生ずる（図 8).

\section{麻酔下食道筋電図}

電極植込み後, いまだ麻酔覚醒がみられぬ状態におい て，食道上部に挿入したビニールチューブより泠水 $10 \mathrm{cc}$ を記入して burst 誘発を試みたが，前述の如き典型的な burst は1例も見られなかった（図 9). しかし，麻酔の 浅い状態では，自発的嚥下による burstに類似するもの がみられた（図 10）。

イヌ No. 3!

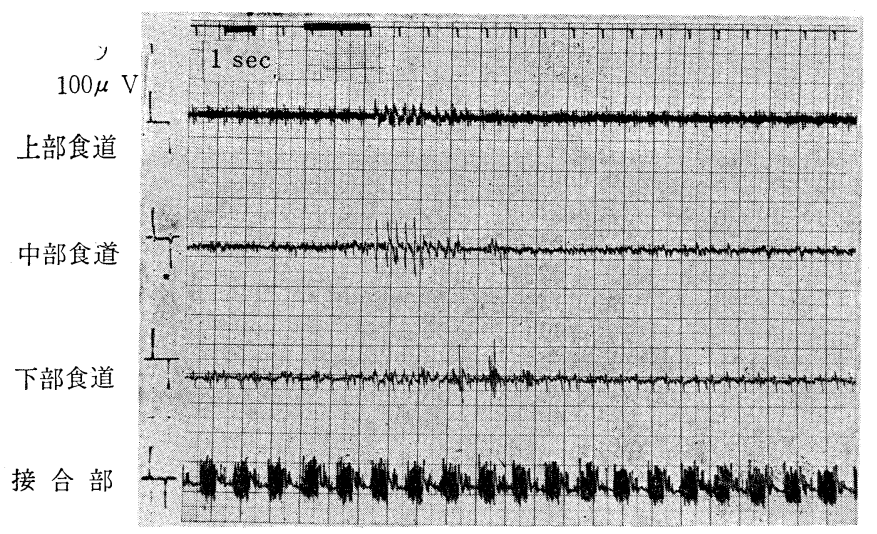

図 9. 冷水注入食道筋電図 (澡麻醉下)

イヌ No. 28

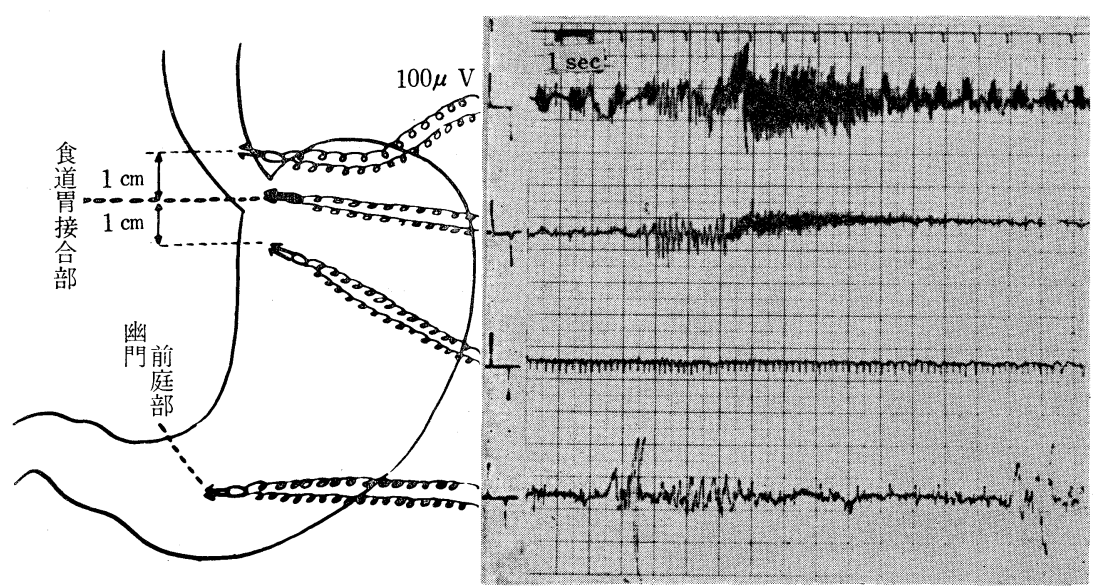

図 10 . 冷水注入食道胃筋電図 (浅麻醉下)

荡

消化管の筋層は平滑筋により構成されるととが多い. たとえば，腸わよび胃は平滑筋よりなり，蠕動運動に一

\section{按}

致する平滑筋活動電位の burst が，ある間隔をもって自 発的に発生する. 一方, 食道は横紋筋および平滑筋より 
なり，その構成割合は動物種差により 異なり9,10,13,14), イヌでは，稲岡は殆んど 全長横紋筋よりなるといい， Ellenberger は食道の下方 5 分の 1 は平滑筋よりなり, それより上部は横紋筋よりなるといっているが, 食道運 動を筋電図の面から見ると, 安静時には心臓運動, 呼吸 運動による活動電位が見られるだけで, 自発的蠕動によ る burst は発生せず, 食道蠕動による burst は㖟下運動 に伴なってはじめて生じた.すなわち, 食道運動は前者 の如き他動的運動と, 後者の如き自動的運動とに大別す る事ができる. 食道の自動的運動とは, 嬹下に伴なう食

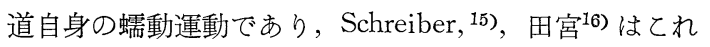
を二相に分け, 第一相では口腔咽頭の嚥下運動により食 物を頸部食道に輸送し, 第二相では胸部食道上端より食 道自身の蠕動運動により輸送が行なわれていると考えて いる. この食道蠕動運動には, 頸部食道に加わった刺激 による全食道の反射的蠕動波である全反射運動と, 伸展 刺激の加わった局所に接する上方から蠕動波が起り下方 におよぶ局所反射運動とがある17 22). 目

これらの他に，食道運動に関する業績は数多くある が, 最近, その研究の焦点は逆流性食道炎, 特発性食道 拡張症の病因・病態究明のため, わずか数 $\mathrm{cm}$ の食道胃 接合部に集まっている23)。乙の部は high pressure zone であり，機能的には括約筋の働きをしており， intrinsic muscle を考えている者もある24 41) が, 解剖学的にその 存在は確証されておらず，横隔膜の影響 ${ }^{42 \sim 44) ， ま た は ， ~}$ 食道胃内圧勾配による弁作用などによりその機序を説明 している者もいる ${ }^{45 \sim 49)}$.

てれらの研究は, 食道鏡による観察, レ線透視映画, 電気圧力計による内圧測定などによりなされているが， 筋電図によるものは少ない.

食道筋電図に関する 最近の 業績としては, 多田 ${ }^{10}$ ) (1959), 水野 ${ }^{11)}$ (1964) があるので, 主に彼等の成績と 比較しつ〉検討する.

多田は家鬼を背位に固定し, 咽頭後壁に挿入してある ビニール細管を通じて微温水 $0.3 \mathrm{cc}$ を注入し, また, 水 野はイヌを Nembutal 麻酔後背位に固定し, 門歯列より $15 \mathrm{~cm}$ 食道内に挿入しているゾンデを通じて水 $10 \mathrm{cc}$

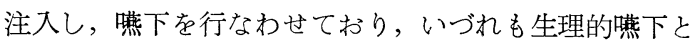
はみなし難い.それに反し，われわれは無麻酔無拘束で 最も生理的な㖟下を行なわせ，食道筋電図を記録し，し かも，経時的に長期間にわたりそれを採取し得た。

慢性植込み電極は，脳波採取用に使われ，胃，または 腸では小野ら50) が使用しているが，食道に於て本法を 採用したのはわれわれが始めてであり，その利点につい ては前述した。

電極刺入は臨床応用を考えると，植田 $\left.{ }^{51}\right) ら ，$ 鈴木 ${ }^{52)}$, 大井 $\left.{ }^{53}\right) ら$, 土田 $\left.{ }^{54}\right)$, 中山 ${ }^{55)}$ ら, Foster ${ }^{56)}$ らの如く，管
内性であるべきだが，食道に於てはその様な報告は少な く, 本教室中山 ${ }^{55}$ ) らの発表があるのみであり，われわ れも，実験的には管外性に電極を刺入した。

電極刺入部位は, 多田の場合, 輪状軟骨下 $1 \mathrm{~cm}$ の頸 部食道，胸骨上窩より $1 \mathrm{~cm}$ 下の胸部食道，および腹部 食道であり，水野の場合，噴門部，およびそれより $5 \mathrm{~cm}$ 上方の下部食道であり，われわれの言う食道胃接合部に は腹部食道 (多田), 郘賁門部（水野）が相当し，下部食 道は水野の言うそれと殆んど同じであり，多田の頸部食 道, 胸部食道はわれわれの上部食道より遙かに上方であ る.また, 水野は single spike, grouping spike, continuous spike の三群にわけ検討しているが，そのうち， grouping spike がわれわれの burst に相当するものであ ろう. 実験動物, 実験方法, 記録装置, burst 測定法な どにより，その結果は一概には論じられないが，その成 績を比較検討してみる. 多田の成績では, burst の最大 振门の平均值は頸部食道で $410 \mu \mathrm{V}$, 胸部食道で $460 \mu \mathrm{V}$, 腹部食道で $540 \mu \mathrm{V}$ となり，また， burst の持続時間の 平均值は頸部食道で 0.17 秒, 胸部食道で 0.18 秒, 腹部 食道で 1.37 秒となり, 両者とも食道下方に行くにつれ 次第に大となっており，われわれの結果とほぼ一致する のだが，われわれの下部食道に相当する部位の測定がな されていないので, 食道胃接合部近傍の食道運動の検討 はできない.てれに反し, 水野は下部食道と噴門部の関 係をみており, grouping spikeの平均振巾の平均值はそ れぞれ $132 \mu \mathrm{V}, 113 \mu \mathrm{V}$ であり，その持続時間は 1.5 秒， 1.3 秒であり，いずれの值も噴門部では小となってお り，われわれの結果と一致する.

食道胃接合部に関して, 大井ら57)はイヌの噴門部では 活動電位は認められないといっているが, 横沢7)ら, 水 野 ${ }^{11)}$ は燕下物刺激による spike の発現を認めており, ま た, 甲田8) は下部食道より噴門に現われる spike は噴門 から $1.5 \mathrm{~cm}$ の胃底部で消失するといっている.てれらの 成績の相違は，噴門部の範囲に関する見解の相違にも起 因する事を考え，esophagogastric junction（食道胃接 合輪）を食道と胃が接する一線とし，ての部とての上下 $1 \mathrm{~cm}$ より筋電図を誘導してみたが，嗌下による burst は 接合論上 $1 \mathrm{~cm}$ に見られ，接合論での burst の振巾はさ らに小さくなり， burst はこの部で終り，接合論より $1 \mathrm{~cm}$ 下では現われなかった。

とてで，食道胃接合部の開閉，緊張について問題にな るが，同時に研究を進めている食道内圧曲線の成績と併 せて，更に検討するつもりである。

さらに，われわれは麻酔下に於て，泠水注入による食

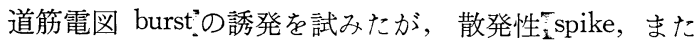
は，非定型的 burst を示すのみであったので，慢性植込 み電極法による典型的 burst は, 食道運動に関して, 最 


\section{結}

われわれは食道運動，ひいては特発性食道㧪張症の病 態生理究明のため, 新たに植込み電極法を食道に於て採 用したが，ての方法の特徽は無麻酔拘束で最も生理的に 近い状態の筋活動が記録でき,さらに, 同一条件で長期 そわたり筋電図を記録できるととである.

ネンブタール麻酔犬を開胸し, 食道の上部, 中部, 下 部, 食道胃接合部に連続的に 4 本の鈞状双極針電極を管 外性に刺入固定し，麻酔覚醒後 3 週間にわたり，食道筋 電図を記録した。

麻酔下冷水注入によっては, burst は明らかではない

\section{論}

が，覚醒後の自発的鯞下によっては著明な burst を見， てれは食道上部より下部へと一定の潜時をおいて次第に 移行した。 この burst は下部に行くにつれ, 最大振巾は 大となり，持続時間は延長したが，食道胃接合部ではて の最大振巾は減少し, 胃では噗下による burst は見られ なかった。

本論文の主旨は第 52 回日本消化機病学会総会で発表 した.

1) Willis, T. : Pharmaceutica rationalis. 1672, cited by Hurst, A.F.: Quart. J. Med., 8, 300, 1915.

2) Alvarez, W.C.: Functional variations in contractions of different parts of the small intestine. Amer. J. Physiol. 35, 177, 1914.

3) Bozler, E.: Electric stimulation and conduction of excitation in smooth muscle. Amer. J. Physiol., 122, 614, 1938.

4) Bozler, E.: The action potentials of visceral smooth muscle. Amer. J. physiol., 124, 502, 1938.

5) von Brücke, E. Th. u. Inoue, T. : Die Aktionsströme der Muskulatur des Kaninchenösophagus bei Reizung der Nervus vagus mit Eingelreizen. Pflüger's Archiv, 145, 152, 1912.

6) von Brücke, E. Th. u. Satake, J. : Úber die Aktionsströme des Kaninchenösophagus während des Ablaufes einer Schluckwelle. Pflüger's Archiv, 150, 208, 1913.

7) 横沢三平：食道機能の笳電図学的研究. 耳鼻咽 㟙科臨床, 49, 705, 1955.

8)甲田博和：燕下及び食道運動に関する笑験的研 究. 耳鼻咽喉科臨床，49,819, 1955.

9) 谷原博公：実験的食道狭窄時に於的る食道機能 の電気生理学的研究. 日外会誌, $58,1590$. 1957.

10) 多田 豊 : 家雭の食道機能の筋電図学的研究. 四国医学会雑誌, 15, 229. 1959.

11）水野秀一：夫に於汁る正常および頝部迷走神経 切断時の下部食道ならびに胃噴門部の電気生理 学的研究. 日大医学雑誌, 23, 1, 1964.

\section{献}

12) 佐藤博ら：筋電図による晹管吻合法の検討. 日 平滑筋誌, 1, 248, 1965.

13) Greving, L.: Lebensnerven u. Lebenstierele：10）多田豊より引用.

14) 大沢 達：食道外科（第 33 回日本外科学会総 会宿題). 日外会誌, 34, 1319, 1933.

15) Schreiber, J.: Arch. f. Verdauungeskrh. 17, 647, 1947.

16)田宮知耻夫：特発性食道拡張症症例補遗. 日新 医学, 14, 241，1924.

17) 水田信夫：食道反射運動に関する実験的研究， 第 1 篇. 食道反射運動の種類. 実験消化器病学, 2, 15, 1927.

18）水田信夫：食道反射運動に関する実験的研究， 第 2 篇. 食道反射運動の促進及び抑制. 実験消 化器病学, 2, 149, 1927.

19) Meltzer, S.J.: On the causes of the orderly progress of the peristaltic movements in the esophagus. Amer. J. Physiol. 2, 266, 1899

20) Carlson, A.J. \& Luckhardt, A.B. : The condition of the esophagus during the periods of gastric hunger contractions. Amer. J. Physiol., 33, 126, 1914.

21）平田和夫：犬食道の局所反射運動に就て. 耳鼻 咽唵科臨床, 26, 97, 1931.

22) 平田和夫：頝部食道外科学補遗, (和辻先生古 稀記念論文), 前篇, 食道の機能に関する実験的 研究. 耳鼻咽喉科臨床, 27, 349, 1932.

23) Mann, C.V. , Greenwood, R.K. \& Ellis, F.H.: The esophagogastric junction. Surg., Gynec. Obstet., 118, 853, 1964.

24) Atkinson, M. et al. : Comparison of cardiac 
and pyloric sphincters; a manometric study. Lancet, 273, 918, 1957.

25) Atkinson, M. et al.: The oesophagogastric sphincter in hiatus hernia. Lancet, 273, 1138, 1957.

26) Atkinson, M.: The oesophagogastric sphincter after cardiomyotomy. Thorax, 14, 115, 1959.

27) Carveth, S. W. et al. : Esophageal motility after vagotomy, phrenicotomy, myotomy, and myomectomy in dogs. Surg. Gynec. Obstet ., 114, 31, 1962.

28) Code, C.F.: The pressure profile of the gastroesophageal sphincter in man: An inproved method of detection. Proc. Staff Meet., Mayo Clin., 33, 406, 1958.

29) Creamer, B., Olsen, A. M \& Code, C.F. : The esophageal sphincters in achalasia of the cardia (Cardiospasm). Gastroenterology, 33, 293, 1957.

30) Creamer, B., Donoghue, F.E and Code, C.F. : Pattern of esophageal motility in diffuse spasm. Gastroenterology, 34, $782,1958$.

31) Creamer, B. \& Schlegel, J. : Motor responses of the esophagus to distention. J. appl. Physiol., 10, 498, 1957.

32) Edwards, D.A.W.: The anti-reflux mechanism : manometric and radiological studies. Brit. J. Radiol., 34, 474, 1961.

33) Fleshler, B. et al.: Resistance and reflex function of the lower esophageal sphincter J. appl. Physiol., 12, 339, 1958.

34) Hightower, Jr, N. C., Olsen, A. M. \& Moersch, H.J.: A comparison of the effects of acetyl-beta-methylcholine chloride (Mecholyl) on esophageal intraluminal pressure in normal persons and patients with cardiospasm. Gastroenterology, 26, 592, 1954.

35) Hightower, N.C. Jr.: Swallowing and esophageal motility. Amer. J. Dig. Dis., 3, 562, 1958.

36) Ingelfinger, F.J. , Kramer, P. \& Sanchez, G.C.: The gastroesophageal vestibule, its normal function and its role in cardiospasm and gastroesophageal reflex. The Amer. J. Med. Sci., 228, 417, 1954.

37) Ingelfinger, F.J.: Esophageal motility. Physiol. Rev., 38, 533, 1958.
38) Ingram, P. R., Respess, J. C. \& Muller, W.H. The role of an intrinsic sphincter mechanism in the prevention of reflux esophagitis. Surg. Gynec. Obstet., 109, $659, \quad 1959$.

39) Nagler, R. \& Spiro, H.M. : Serial esophageal motility studies in asymptomatic young subjects. Gastroenterology, 41, 371, 1961.

40) Botha, G.S.M., Astley, R. \& Carré, I.J. A combined cineradiographic and manometric study of the gastrooesophageal junction. Lancet, 272, 659, 1957.

41) Botha, G.S.M.: Mucosal folds at the cardia as a component of the gastroesophageal closing mechanism. Brit. J. Surg. 45, 569, 1958.

42) Allison, P.R.: Reflux esophagitis, sliding hiatal hernia and the anatomy of repair. Surg. Gynec. Obstet., 92, 419, 1951.

43) Jackson, C. The diaphragmatic pinchcock in so-called "Cardiospasmus". Laryngoscope, (St. Louis), 32, 139, 1922.

44）新妻伸二：食道青接合部周辺の機能の問題（第 2報)。臨床消化器病学, 7, 266, 1959.

45) Adler, R.H., Firme, C.N. \& Lamigan, J.M.: A value mechanism to prevent gastrosophageal reflux and esophagitis. Surgery, 44, 63, 1958.

46) Collis, J.L., Kelly, T.D. \& Wiley, A. M.: Anatomy of the crura of the diaphragm and the surgery of hiatus hernia. Thorax, 9., 175, 1954.

47) Creamer, B. \& Pierce, J.W. : Observations on the gastroesophageal junction during swallowing and drinking. Lancet, 273, 1309, 1957.

48) Dornhorst, A.C., Harison, K. \& Pievce, J. W.: Observation on the normal oesophagus and cardia. Lancet, 266, 695, 1954.

49) Dornhorst, A.C., Pierce, J.W. and Whinster, I.W.: The oesophageal lesion in scleroderma. Lancet, 266, 698, 1954.

50) 小野慶一ら：横隔膜下胃底部切除術之幽門部 括約筋機能. 外科治療, 11, 127, 1964.

51) 植田 隆, 鈴木三郎：人腸管の動作電流とその 臨床応用について. 日外会誌，57, 605, 1956.

52) 鈴木三郎：腸運動の動作電流，第 1 篇, 腸管 動作電流の臨床的誘導法. 日外会誌, $\mathbf{5 8}, \mathbf{1 9 2 0}$, 
1957.

53) 大井 実ら：胃運動機能と胃壁内神経細胞との 関係に関する臨床的研究. 臨床消化器病学, 9, 19, 1961.

54）土田正義ら：腸管筋電図の管内誘導法. 治療, 47, 1851， 1965.

55）中山恒明ら：噴門痤卛症（噴門無驰緩症）の病 態生理 病理とその外科的治療法.外科治療, 10,
255, 1964.

56) Forster, F.M., Helm, J.D. Jr. and Ingelfinger, F.J.: The electric potentials of the human small intestine. Amer. J. Physiol., 139, 433, 1943.

57) 大井 実ら：胃運動機能に関する筋電図学的研 究. 外科, 25, 1333, 1963. 